\title{
ANTIMICROBIAL ACTIVITY OF AQUEOUS AND ETHANOLIC LEAF EXTRACTS OF ANACARDIUM OCCIDENTALE
}

\author{
SHOBHA KL ${ }^{1}$, AMITA SHOBHA RAO ${ }^{1 *}$, PAI KSR ${ }^{2}$, SUJATHA BHAT ${ }^{1}$ \\ ${ }^{1}$ Department of Microbiology, Melaka Manipal Medical College (Manipal Campus), Manipal Academy of Higher Education, Manipal, \\ Karnataka, India. ${ }^{2}$ Department of Pharmacology, Manipal College of Pharmaceutical Sciences, Manipal Academy of Higher Education, \\ Manipal, Karnataka, India. *Email: amitarao@rediffmail.com \\ Received: 13 August 2018, Revised and Accepted: 17 September 2018
}

ABSTRACT

Objective: The objective of this study was to evaluate the antimicrobial activity of leaves of Anacardium occidentale (A. occidentale) against microorganisms including multidrug-resistant (MDR) bacteria.

Methods: Agar well diffusion method was employed to demonstrate the antimicrobial activity of leaves A. occidentale. Ethanol and aqueous extracts of the leaves were used against microorganisms, which included American type culture collection strains of Staphylococcus aureus, Escherichia coli, Klebsiella pneumoniae, Enterococcus faecalis, and Pseudomonas aeruginosa and the clinical isolates of Streptococcus pneumoniae, Candida albicans, MDR Escherichia coli, and MDR Klebsiella pneumoniae.

Results: The ethanolic extract of leaves of A. occidentale showed significant antimicrobial activity. Aqueous extract had mild antifungal activity.

Conclusion: Ethanolic extract of leaves of $A$. occidentale could be a good source for the antibacterials to combat MDR bacterial infections. Further studies are necessary for these potent plant extracts to evaluate the in vivo efficacy and toxicity.

Keywords: Leaves of Anacardium occidentale, Antimicrobial susceptibility testing, Multidrug-resistant bacteria.

(C) 2018 The Authors. Published by Innovare Academic Sciences Pvt Ltd. This is an open access article under the CC BY license (http://creativecommons. org/licenses/by/4. 0/) DOI: http://dx.doi.org/10.22159/ajpcr.2018.v11i12.29073

\section{INTRODUCTION}

Multidrug resistance (MDR) is increasing both in community and health-care associated bacterial infections worldwide. This has impaired the current antimicrobial therapy, thereby creating a demand for other alternatives. There is a demand for medicinal plants in health-care system and the use of these has been associated with fewer side effects [1]. Nowadays, bacteria such as Staphylococcus aureus (S. aureus), Escherichia coli (E. coli), Klebsiella pneumoniae (K. pneumoniae), and Enterobacter species have acquired resistance to the commonly used antibiotics [2-5]. The treatment options for these microorganisms are less and treating physicians are compelled to use expensive drugs like colistin that is associated with significant side effect to the patient's health [6]. Therefore, there is a need for the development of alternate drugs to prevent the infections caused by these organisms. Medicinal plants are rich sources of antimicrobial agents. Herbal plants have attained a significant role as therapeutic agents [7]. Anacardium occidentale (A. occidentale) a native of Brazil, a tropical evergreen tree, almost all the plant parts, namely bark, leaves, fruit, flower, and nut oil, have been reported to be useful to cure many diseases such as venereal diseases, diarrhea, skin diseases, stomatitis, bronchitis, psoriasis, toothaches, and gum problems [8-10]. Leaves of which contain pharmacologically rich components such as alkaloids, essential oils, tannins, saponins, and cardenolides [11, 12] and are known to have cosmetic [13], antimicrobial [14], and antioxidant [15] properties. In this study, antimicrobial activity against selected bacterial and fungal strains was performed using ethanol and aqueous extract of A. occidentale leaves.

\section{MATERIALS AND METHODS}

\section{Plant collection}

The fresh leaves of $A$. occidentale were collected from the plantation area of Udupi, Karnataka, India. Its botanical identity was authenticated by a botanist.
Aqueous and ethanol extraction

Leaves of $A$. occidentale were washed with distilled water and air dried at room temperature for 10 days. Fine powder was made by pulverizing with clean mortar and pestle, then stored in a sterilized glass container at room temperature $\left(25-30^{\circ} \mathrm{C}\right)$.

By Soxhlation method, the ethanol extract of leaves was prepared [16]. The aqueous extract of the leaves was prepared by crushing the leaves in mortar and pestle using sterile distilled water in the ratio of 1:1.

\section{Antimicrobial activity}

Agar well diffusion method was employed to study the antibacterial and antifungal susceptibility [17]

Antimicrobial susceptibility was determined using American type culture collection (ATCC) strains, MDR strains, and fungus. The ATCC strains were $S$. aureus ATCC 25923, Enterococcus faecalis ATCC 29212, K. pneumoniae ATCC 700603, E. coli ATCC 25922, and Pseudomonas aeruginosa ATCC 27853 and clinical strains of Streptococcus pneumoniae (S. pneumoniae), MDR E. coli, MDR K. pneumoniae, and Candida albicans (C. albicans). Ampicillin disc $(10 \mu \mathrm{g})$, oxacillin disc $(1 \mu \mathrm{g})$, gentamicin disc $(10 \mu \mathrm{g})$, and ketoconazole disc $(10 \mu \mathrm{g})$, obtained from Hi-Media, Mumbai, were used as controls.

Culture media used were Sabouraud's dextrose agar (SDA), MullerHinton agar (MHA), and blood agar (for S. pneumoniae) which were procured from Hi-Media, Mumbai. The above-mentioned bacterial and fungal strains were identified by standard procedure. Isolated bacterial colonies were transferred to sterile Mueller-Hinton broth, and C. albicans was inoculated to Sabouraud's dextrose broth and incubated at $37^{\circ} \mathrm{C}$ overnight. The concentration of growth of microorganisms to $10^{5} \mathrm{CFU} / \mathrm{ml}$ was adjusted using 0.5 McFarland's turbidity standard 
Determination of antibacterial activity

Blood agar and MHA measuring $20 \mathrm{ml}$ each was poured into Petri dishes. The bacterial culture was spread over the surface of the MHA plate and blood agar. Wells of $6 \mathrm{~mm}$ diameter were punched into the agar and filled with $100 \mu \mathrm{l}$ of the solution. The inoculated plates were incubated at $37^{\circ} \mathrm{C}$ for $18 \mathrm{~h}$. Tests were performed in triplicates and the average of the three was considered for the study.

\section{Determination of antifungal activity}

$20 \mathrm{ml}$ of SDA was poured into each Petri dish. Culture of the C. albicans was spread over the surface of the SDA plate. Wells were punched into the agar plate measuring $6 \mathrm{~mm}$ in diameter and filled with $100 \mu \mathrm{l}$ solution. The plates were further incubated for $18 \mathrm{~h}$ at $37^{\circ} \mathrm{C}$. Tests were done in triplicates and the average of the three was considered for the study.

\section{RESULTS}

Diameter of zone of inhibition was measured for antimicrobial activity. Ethanol extract of $A$. occidentale leaves exhibited antibacterial activity against all the bacterial strains. The zone of inhibition for $E$. coli ATCC 25922 was $20 \mathrm{~mm}$ and $S$. aureus ATCC 25923 was $18 \mathrm{~mm}$. Zone of inhibition for MDR strains of E. coli was $18 \mathrm{~mm}$ and K. pneumoniae $15 \mathrm{~mm}$. All the bacterial strains were resistant to aqueous extract of $A$. occidentale leaves. Both the aqueous and ethanolic extracts of $A$. occidentale leaves were found to have antifungal activity $\mathrm{p}<0.05$ [Table 1].

\section{DISCUSSION}

Antimicrobial resistance is the most common prevailing problem in the present scenario. The microorganisms employ new mechanisms to survive [18]. S. aureus, K. pneumoniae, E. coli, and Streptococcus pneumoniae are some of the most important organisms exhibiting MDR. Development of alternative drugs to treat infectious diseases caused by such organisms is essential. The herbal drugs obtained from the medicinal plants have fewer adverse effects than the conventional ones. In this study, the ethanolic extract of A. occidentale leaves showed significant antibacterial activity against clinically isolated MDR microorganisms. Although the mechanism of the action of these plant constituents is not yet fully known, we observed that ethanolic extract provided antimicrobial activity.

Venkatadri et al. and Girish et al. [19,20] in their study reported that the effectiveness of extracts largely depends on the type of solvent used and ethanolic extracts exhibited greater antibacterial activity than the corresponding aqueous extracts. Our study was in concordance with their study. These findings could be due to the ability of the solvent to extract more active ingredients from the plant materials [21]. Most of the antibiotic compounds such as plant alkaloids and tannins were reported as antibacterial substances [22] and were better extracted using ethanol than water. Belonwu et al. and Krishnananda

Table 1: Zone of inhibition of ethanol and aqueous leaf extract of $A$. occidentale against various microorganisms

\begin{tabular}{lll}
\hline Name of the organism & \multicolumn{2}{l}{ Zone of inhibition (mm) } \\
\cline { 2 - 3 } & $\begin{array}{l}\text { Ethanol } \\
\text { extract }\end{array}$ & $\begin{array}{l}\text { Aqueous } \\
\text { extract }\end{array}$ \\
\hline Staphylococcus aureus ATCC 25923 & 18 & - \\
Enterococcus faecalis ATCC 29212 & 12 & - \\
Klebsiella pneumoniae ATCC 700603 & 18 & - \\
Escherichia coli ATCC 25922 & 20 & - \\
Pseudomonas aeruginosa ATCC 27853 & 16 & - \\
Streptococcus pneumoniae & 17 & - \\
MDR Escherichia coli & 18 & - \\
MDR Klebsiella pneumoniae & 15 & - \\
Candida albicans & 17 & 9 \\
\hline
\end{tabular}

(-): Indicates no zone of inhibition, ATCC: American type culture collection, MDR: Multidrug resistant et al. $[23,24]$ on systemic evaluation of antibacterial activity of A. occidentale reported that alkaloids, saponins, flavonoids, tannins, hydrogen cyanide, phenols, and anthocyanin present in the leaf were responsible for the antibacterial activity. They showed that $S$. aureus, $E$. coli, P. aeruginosa, and K. pneumoniae were greatly inhibited by ethanolic leaf extract. Dahake et al. [14] also reported similar results.

In our study, both the aqueous and ethanolic extract of $A$. occidentale leaves showed antifungal activity against $C$. albicans. This bioactivity might be due to antifungal components such as alkaloids, lectins, terpenes, and saponins which is easily extracted by water $[25,26]$

\section{CONCLUSION}

This study shows that ethanolic extract of $A$. occidentale leaves had antimicrobial activity against pathogenic microorganisms including MDR strains. Further studies are necessary to evaluate the component responsible for antimicrobial activity of this plant for pharmaceutical applications.

\section{AUTHORS' CONTRIBUTION}

All the authors have substantially contributed to the research and publication of this study.

\section{CONFLICTS OF INTEREST}

The authors have no conflicts of interest to declare.

\section{REFERENCES}

1. Ratnam VK, Md LB, Padma Y, Venkata RR. Studies on antimicrobial and antioxidant properties of leaf extracts of Syzygium alternifolium (wt.) Walp. Int J Pharm Pharm Sci 2014;7:139-43.

2. Grundmann H, Aires-de-Sousa M, Boyce J, Tiemersma E. Emergence and resurgence of meticillin-resistant Staphylococcus aureus as a public-health threat. Lancet 2006;368:874-85

3. Ariza RR, Cohen SP, Bachhawat N, Levy SB, Demple B. Repressor mutations in the mar RAB operon that activate oxidative stress genes and multiple antibiotic resistance in Escherichia coli. J Bacteriol 1994:176:143-8.

4. Kidd TJ, Mills G, Sa Pessoa J, Dumigan A, Frank CG, Insua JL, et al. A Klebsiella pneumoniae antibiotic resistance mechanism that subdues host defenses and promotes virulence. EMBO Mol Med 2017;9:430-47.

5. Davin-Regli A, Pagès JM. Enterobacter aerogenes and Enterobacter cloacae; Versatile bacterial pathogens confronting antibiotic treatment. Front Microbiol 2015;6:1-10

6. Boucher HW, Talbot GH, Bradley JS, Bartlett JG, Edwards JE, Gilbert DN, et al. Bad bugs, no drugs: No ESKAPE! An update from the infectious diseases society of America. Clin Infect Dis 2009;48:1-12.

7. Parasa LS, Tumati SR, Kumar LC, Chigurupati SP, Rao GS. In vitroantimicrobial activity of cashew (Annacardium occidentale, L.) nut shell liquid against methicillin resistant Staphylococcus aureus (MRSA) clinical isolates. Int J Pharm Pharm Sci 2011;3:436-40.

8. Goncalves JL, Lopes RC, Oliveira DB, Costa SS, Miranda MM, Romanos MT, et al. In vitro antirotavirus activity of some medicinal plants used in Brazil against diarrhea. J Ethnopharmacol 2005;99:403-7.

9. Obaineh OM, Shadrach A. Phytochemical constituents and medicinal properties of different extracts of Anacardium occidentale and Psidium guajava. Asian J Biomed Pharm Sci 2013;3:20-3.

10. Aracelli de SL, Md Torequl I, Antonio LG, Sousa JM, de Alencar MV, Paz MF, et al. Review on pharmacological properties of cashew (Anacardium occidentale). Afr J Biotechnol 2016;15:1855-63.

11. Rao AS, Nayanatara AK, Kaup SR, Sharma A, Kumar BA, Bhavesh D, et al. Potential antibacterial and antifungal activity of aqueous extract of Cynodon dactylon. Int J Pharm Sci Res 2011;2:2889-93.

12. Onasanwo SA, Fabiyi TD, Oluwole FS, Olaleye SB. Analgesic and antiinflammatory properties of the leaf extracts of Anacardium occidentale in the laboratory rodents. Niger J Physiol Sci 2012;27:65-71.

13. Gonçalves GM, Gobbo J. Antimicrobial effect of Anacardium occidentale extract and cosmetic formulation development. Braz Arch Biol Technol 2012;55:843-50.

14. Dahake AP, Joshi VD, Joshi AB. Antimicrobial screening of different extract of Anacardium occidentale Linn. Leaves. Int J Chem Tech Res 2009;1:856-8. 
15. Onuh JO, Idoko G, Yusufu P, Onuh F. Comparative studies of the phytochemical, antioxidant and antimicrobial properties of cashew leaf, bark and fruits extracts. Am J Food Nutr 2017;5:115-20.

16. Shakya VK, Saxena S, Shakya A. Effect of ethanolic extract of Allium sativum bulbs on streptozotocinet induced diabetic rats. J Chem Pharm Res 2010;2:171-5.

17. Murray PR, Baron EJ, Pfaller MA, Tenover FC, Yolken HR. Manual of Clinical Microbiology. $6^{\text {th }}$ ed. Washington DC: ASM Press; 1995. p. 15-8.

18. Sekyere JO, Asante J. Emerging mechanisms of antimicrobial resistance in bacteria and fungi: Advances in the era of genomics. Future Microbiol 2018;13:241-62.

19. Venkatadri B, Arunagirinathan N, Rameshkumar MR, Latha R, Dhanasezhian A, Agastian P. In vitro antibacterial activity of aqueous and ethanol extracts of Aristolochia indica and Toddalia asiatica against multidrug-resistant bacteria. Indian J Pharm Sci 2015;77:788-91.

20. Girish HV, Satish S. Antibacterial activity of important medicinal plants on human pathogenic bacteria-a comparative analysis. World Appl Sci J 2008;5:267-71.
21. Cowan M. Plant products as antimicrobial agents. Clin Microbiol Rev 1999; 12:564-82.

22. Santos FO, Angélico EC, da Costa JG, Rodrigues FF, Rodrigues OG, Severo de Medeiros R. Antibacterial evaluation of Anacardium occidentale (Linn) (Anacardiaceae) in semiarid Brazil. Afr J Biotechnol 2013;12:4836-40.

23. Belonwu DC, Ibegbulem CO, Chikezie PC. Systemic evaluation of antibacterial activity of Anacardium occidentale. J Phytopharmacology 2014;3:193-9.

24. Krishnananda KK, Ramakrishna SA. Comparison of antibacterial activity of leaves extracts of Tectona grandis, Mangifera indica, and Anacardium occidentale. Int J Curr Pharm Res 2017;9:36-9.

25. Klafke GB, Moreira GM, Monte LG, Pereira JL, Brandolt TM, Xavier MO. Assessment of plant lectin antifungal potential against yeasts of major importance in medical mycology. Mycopathologia 2013;175:147-51.

26. Kannan VR, Sumathi CS, Balasubramanian V, Ramesh N. Elementary chemical profiling and antifungal properties of cashew (Anacardium occidentale L.). Bot Res Int 2009;2:253-7. 